\title{
Rapid Detection and Identification Systems for the Microbiological Assessment of Processed Soy Foods: A Review
}

\author{
Mitsuru Katase $^{1}$ \& Kazunobu Tsumura ${ }^{2}$ \\ ${ }^{1}$ Fuji Oil Co., Ltd., Osaka, Japan \\ ${ }^{2}$ FUJI OIL HOLDINGS INC., Osaka, Japan \\ Correspondence: Kazunobu Tsumura, FUJI OIL HOLDINGS INC., 1 Sumiyoshi-cho, Izumisano-shi, Osaka \\ 598-8540, Japan. Tel: 81-72-463-1751. E-mail: tsumura.kazunobu@ @o.fujioil.co.jp
}

Received: June 16, 2020

Accepted: July 17, 2020

Online Published: July 22, 2020

doi:10.5539/jfr.v9n5p22

URL: https://doi.org/10.5539/jfr.v9n5p22

\begin{abstract}
Plant-based diets are gaining interest in promoting physical and environmental health worldwide. The widely growing consumption of processed soy foods results in an increased demand for safe and high quality soy foods. Many of the rapid bacterial detection methods currently available are inhibited by components in the food matrixes. In recent years, high-throughput devices have been developed, which aid in the enumeration and evaluation of microorganisms in processed soy foods (automated fluorescent filter method, high-throughput identification using matrix-assisted laser desorption ionization time-of-flight mass spectrometry, and automated most probable number method). These methods are more rapid and convenient compared to the conventional culture method. This review discusses alternate reliable methods for the microbiological assessment of processed soy foods, which guarantees the safety of the food delivered for consumption.
\end{abstract}

Keywords: soy foods, microorganisms, risk assessment

\section{Introduction}

Microorganisms are one of the most important food quality indicators. The consistent manufacture of safe, high-quality foods requires a well-planned hygiene program aimed at controlling and reducing bacterial contamination during and post-processing.

The Japanese food culture has been added to the UNESCO's intangible cultural heritage list (UNESCO, 2013). Soy foods are one of the representatives of the Japanese "Washoku" culture. Therefore, development of analytical methods for the microbiological risk assessment of soy foods is a great importance.

Soybean is one of the most prominent protein sources, and the balance of essential amino acids is similar to that of milk and eggs. Various kinds of soy foods are commercially available. Soy protein isolate is a highly refined powdered protein that has good gelation and emulsifying properties (Hettiarachchy \& Kalapathy, 1997; Tsumura, 2009). It is also used as an ingredient in a healthy diet, targeting those with high cholesterol levels. Additionally, soybeans are attracting the most attention among plant proteins, for use as a sustainable protein source (Thrane et al., 2017).

On the other hand, there is little microbial information on processed soy foods (Table 1). Soil-derived Bacillus, found in soybean, is the main flora in processed soy foods, and is one of the targets in the sanitation management program (Zhou et al., 2017). 
Table 1. Main bacteria isolated from processed soy foods

\begin{tabular}{|c|c|c|}
\hline Items of foods & Detected bacteria & Reference \\
\hline Tofu & $\begin{array}{l}\text { Streptococcus, Pediococcus, Lactobacillus, Pseudomonas, } \\
\text { Pseudomonas, Enterobacter, Enterobacter }\end{array}$ & Tuitemwong \& Fung, 1991 \\
\hline Tofu & $\begin{array}{l}\text { Coliforms, Pseudomonas, Escherichia, Enterococcus, } \\
\text { Lactic acid bacteria, Bacillus, Staphylococcus }\end{array}$ & Ananchaipattana et al., 2012 \\
\hline Tempeh & $\begin{array}{l}\text { Enterobacteriaceae, Lactic acid bacteria, Staphylococcus, } \\
\text { Bacillus, Escherichia }\end{array}$ & Samson et al., 1987 \\
\hline Kinema & Bacillus, Enterococcus & Sarkar et al., 1994 \\
\hline Sufu & Mesophilic aerobic bacteria, Lactic acid bacteria & Han et al., 2001 \\
\hline Doenjang & Leuconostoc, Tetragenococcus, Enterococcus, Bacillus & Kim et al., 2009 \\
\hline Meju & Bacillus, Enterococcus, Pediococcus & Kim et al., 2011 \\
\hline Cheonggukjang & Bacillus, Lactic acid bacteria & Nam et al., 2012 \\
\hline Denjang-meju & Bacillus & Jung et al., 2014 \\
\hline Stinky tofu & Streptococcus, Lactococcus & Gu et al., 2018 \\
\hline
\end{tabular}

Traditionally, microorganisms in processed soy foods and other retail foods have been evaluated by standard plate count on selective media (International Organization for Standardization, 2003; Official methods of Analysis Online, 2005). However, these methods usually take more than a day to detect the microorganisms (Vasavada \& White, 1993). Therefore, a rapid, accurate and simple method is desirable.

Several rapid detection methods are used in the food industry (Gracias \& McKillip, 2004). Polymerase chain reaction (PCR) is one of the most commonly used techniques due to its high sensitivity. In particular, reverse transcription PCR is a valuable method for detecting viable bacteria. However, this method needs to extract nucleic acids from the food samples. In addition, lipids and proteins in food can often interfere with PCR, necessitating the development of other methods (Gadkar \& Filion, 2013; Schrader et al., 2012). Fluorescence staining method is widely used for microbial detection without culturing (Miyanaga et al., 2007; Yamaguchi et al., 2007), and flow cytometry is used to count viable bacterial cells (Diaper et al., 1992; Jepras et al., 1995; Khan et al., 2010).

Matrix-assisted laser desorption ionization time-of-flight mass spectrometry (MALDI-TOF MS) has recently been shown to be a rapid and reliable method for bacterial identification (Lay, 2001; Mazzeo et al., 2006). The speed and accuracy of MALDI-TOF MS is widespread as a routine bacterial identification method in food microbiology (Angelakis et al., 2011; Böhme et al., 2011; Hochel et al., 2012; Kuda et al., 2014). Bacterial identification using MALDI-TOF MS eliminates the shortcomings of conventional culture methods because the time required for bacterial identification is very short. However, it is difficult to detect and identify bacteria in high lipid-containing food. Moreover, little information is available on non-culture based bacterial identification in food samples using the MALDI-TOF MS (Barreiro et al., 2012; Ferreira et al., 2010; Furukawa et al., 2013; Katase \& Tsumura, 2014).

There are many alternatives methods that have been validated by protocols based on the international certification ISO 16140 standard. Petrifilm method is one of the widely applied methods (Freitas et al., 2009; Silva et al., 2005; de Sousa et al., 2005). This method is convenient and reliable, but is labor intensive. Therefore, a simple and automated method is required for quality assurance in the food industry.

In this review, alternate rapid methods of microbial assessment for the safety of processed soy foods, are discussed.

\section{Automated Microbial Cell Counting System with Fluorescent Staining in Processed Soy Foods}

Microbiological contamination of processed foods is a key issue in the food industry. Traditional methods serve as a reference for the microbiological quality control of food products, as they are reliable and easy to use for microorganism identification. However, these methods are time consuming and labor intensive. Moreover, they depend on the ability of microorganisms to form visible colonies after an incubation period of typically one to three days. This long time-to-result is an issue for food industries, as process improvement requires the availability of faster methods to control microbiological quality.

Consequently, a lot of technologies have been developed to reduce the time to result. These alternate technologies need to be accurate, sensitive and cost-effective. One of the most representative technologies is the fluorescent filter method (Boulos et al., 1999; Lahtinen et al., 2006; Ootsubo et al., 2003; Pettipher \& Rodrigues, 
1982).

Bioplorer (Koyo Sangyo Co., Ltd), an optical device designed for measuring microbial count in cosmetics, toiletries and foods, has been reported (Arai et al., 2006; Masakiyo et al., 2010; Nishimura et al., 2006; Nishimura et al., 2008; Shimakita et al., 2006; Shimakita et al., 2007). This device consists of a charge-coupled device camera, an optical unit, a light emitting diode (LED) light source, and a driving stage (Figure 1). Fluorescent dyes such as 4, 6-diamidino-2-phenylindole or propidium iodide are used for microbial staining on a sampling tip, followed by placing the tip on the instrument for automated counting. The advantage of an automated cell counting system is that, it requires much less time compared to microscopy, which consumes more than one hour even if measured by a skilled person (Yamaguchi et al., 2003). Although previous studies have demonstrated that this system could successfully enumerate bacterial cells in various food samples (Shimakita et al., 2006), colloidal and proteinaceous fluid such as soymilk and soy protein isolate solutions are exceptions, owing to filtration problems. To separate microorganisms from a proteinaceous fluid, a conventional isoelectric precipitation method, which is commonly used for the production of soy protein isolates (Petenate \& Glatz, 1983; Tsumura et al., 2004).

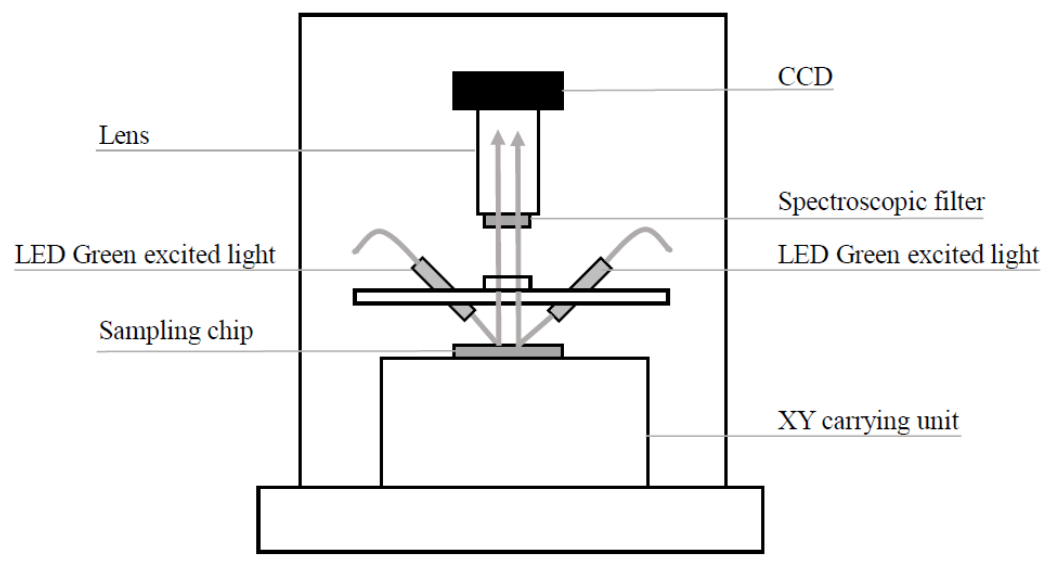

Figure 1. Schematic of the LED-illuminated detection apparatus

Tsumura and Tsuboi (2012) demonstrated that the total bacterial cells in solubilized soymilk could be enumerated using the automated cell counting system. However, for accurate viable cell count, the separation of microorganisms from the complex food matrix is essential (Araki et al., 2010; Benoit \& Donahue, 2003; Fukushima et al., 2007; Stevens \& Jaykus, 2004). On removal of the food matrix, this system can be implemented and the viable cell count can be obtained by staining with 6-carboxyfluorescein diacetate. Katase et al. (2013) demonstrated the use of this system, combined with a bacterial cell recovery method, in the enumeration of coliforms present in processed soy products. Bacilli are sometimes present as contaminants in processed soy foods (Fang et al., 1999; Pascall et al., 2006). For preferential coliform detection, culture enrichment of coliforms with brilliant green and sodium deoxycholate is performed within $6 \mathrm{~h}$. This method was faster than other conventional methods for detecting trace levels of coliforms in soymilk. An in-house verification test has also been performed, according to the AOAC guidelines (Feldsine et al., 2002), to verify the applicability of this method for the detection of coliforms. This method did not give false positive or false negative results, resulting in higher sensitivity and specificity. A chi square value well below the threshold indicated that the method under investigation, and the reference method, were not statistically different. This alternate technique is more rapid and convenient than the conventional plate count method. Thus, it can be used to quickly detect coliform contamination in processed soy foods such as soymilk. Further improvements are needed for actually detecting specific bacteria by fluorescent in-situ hybridization staining (Nishimura et al., 2008; Yamaguchi et al., 2009).

\section{MALDI-TOF MS Identification of Bacteria in Processed Soy Foods}

In recent years, a rapid method for bacterial identification in processed soy foods using the MALDI-TOF MS system has been generalized (Table 2). However, the fat matrixes in foods interfere with accurate identification of bacteria using the MALDI-TOF MS system. Katase \& Tsumura (2014) found that the identification accuracy of MALDI-TOF MS was lower when the fat content of the soymilk sample was $\geq 50 \%$, indicating that the residual fat matrixes might have interfered with the raw mass spectrum and affected the spectrum matching. 
Table 2. MALDI-TOF MS bacterial identification of processed soy foods

\begin{tabular}{lll}
\hline Items of foods & Identified bacteria & Reference \\
\hline Korean fermented foods & Weissella & Kim et al., 2017 \\
Korean soybean paste (doenjang) & $\begin{array}{l}\text { Bacillus, Paenibacillus, } \\
\text { Tetragenococcus, Stapylococcus, Clostridium }\end{array}$ & Woo et al., 2015 \\
Soy sauce & Tetragenococcus & Kuda et al., 2014 \\
Fried-Tofu, Soy milk & Enterobacter, Klebsiella, & Katase \& \\
& Escherichia, Enterobacter & Tsumura, 2014 \\
Soy milk, Tofu, Frozen tofu, Dried tofu & Leuconostoc, Serratia, Bacillus, Raoultella & Furukawa et al., 2013 \\
Tofu & Cronobacter & Hochel et al., 2012 \\
\hline
\end{tabular}

Other rapid detection methods, such as PCR, are also inhibited by fat matrixes (Gadkar \& Filion, 2013; Schrader et al., 2012). According to the International Organization for Standardization (2010), in the bacterial inspection of butter, it is essential to remove the fatty phase.

Katase \& Tsumura (2014) demonstrated the separation of coliforms in processed soymilk, using an isoelectric precipitation method, practically applied to produce soy protein isolates (Petenate \& Glatz, 1983; Tsumura et al., 2004), in combination with surfactant (sodium dodecyl sulfate) treatment. As a result of this treatment, accurate identification scores were obtained in soymilk samples with high fat content, using the MALDI-TOF MS system.

Contamination of processed foods is not always due to a single bacterial species. However, the coliform concentration in commercially available processed foods is relatively low. The dominant bacterial species in the food product can be identified by selective enrichment methods. The coliforms isolated from commercial soy foods belong to the Enterobacteriaceae family (Ananchaipattana et al., 2012; Préstamo et al., 2000). Currently, confirmation test is required following the successful detection of coliforms cultured in brilliant green-bile-lactose broth. On the other hand, since MALDI-TOF MS can directly identify bacterial cells, these confirmation tests are not required. Due to the discriminatory capabilities of MALDI-TOF MS, this direct bacterial identification method can be used in the food industry for quality control, process monitoring, and for confirming the presence of bacteria detected by other tests.

\section{Automated Enumeration System Based on the Most Probable Number (MPN) Method}

Most probable number (MPN) is the primary method for the enumeration of food borne bacteria since it can detect low bacterial levels. However, MPN method is labor intensive and time consuming. TEMPO is an automated enumeration system based on the MPN method for bacterial enumeration in food samples (Kobayashi et al., 2008; Kunicka, 2007; Owen et al., 2010; Paulsen et al., 2006; Paulsen et al., 2008: Torlak et al., 2008;). It is an internationally recognized method validated by ISO and the AOAC, and evaluated in various foods (Crowley et al., 2009; Crowley et al., 2010; Jasson et al., 2010).

Artificially contaminated processed soy products (soy protein isolate, soybean soluble polysaccharides, soymilk and tofu) were evaluated using different TEMPO kits (total aerobic bacteria; total coliform; Enterobacteriaceae; yeast and mold; Staphylococcus aureus). A high Pearson correlation coefficient was seen between the TEMPO and standard plate method, and no statistically significant difference was observed between the two methods (Katase \& Tsumura, 2011).

The standard plate method requires time, materials, and is labor intensive (Vasavada \& White, 1993). The confidence that the method has been executed accurately often depends on the skills of the staff. A non-technical staff may not be able to distinguish between a microbial colony and a food particle while performing the bacterial count.

Accurate results were obtained for majority of the processed soy food samples using the TEMPO method. Occasionally, in richly colored soy foods (soy sauce) and fermented soy foods (natto), some results were anomalous. This system provides improved standardization and minimizes economic loss, in terms of labor, by eliminating dilutions, preparation of medium, and plate counting. Therefore, TEMPO is a reliable alternate method for the microbial testing of processed soy foods.

\section{Next Generation Sequencing Technique for Microbiological Risk Assessment}

In recent years, the next generation sequencer has brought about innovation in microbial analysis (Table 3). In Food and Drug Administration (FDA), and Centers for Disease Control and Prevention (CDC), routine whole genome sequencing (WGS) has successfully identified the sources of food-borne pathogen contamination 
(Rantsiou et al., 2018). Without relying on WGS, the analysis of the flora contained in food samples has been successfully examined using the 16S ribosomal RNA sequencing method (Jagadeesan et al., 2019). The 16S metagenomic analysis can be used routinely to evaluate the bacterial quality of food ingredients (Patro et al., 2016). At present, the hurdles are high in terms of cost, for the food companies to use these techniques easily. However, this technology will be used actively in the future for microbiological risk assessment.

Table 3. 16S amplicon sequencing approach for microbial assessment of processed soy foods

\begin{tabular}{|c|c|c|}
\hline Items of foods & Target bacteria & Reference \\
\hline Fermented soybean products & $\begin{array}{l}\text { Lactobacillus, Enterococcus, } \\
\text { Fructobacillus, Staphylococcus, } \\
\text { Carnobacterium }\end{array}$ & Xie et al., 2019 \\
\hline Soy-daddawa, fermented indigenous food & Bacillus, Staphylococcus & Ezeokoli et al., 2018 \\
\hline Da-jiang, fermented soybean condiment & Staphylococcus, Leuconostoc & Wu et al., 2018 \\
\hline Fermented soybean foods & Bacillus, Tetragenococcus, Enterococcus & Lee et al., 2017 \\
\hline Soybean pastes & $\begin{array}{l}\text { predominant phyla (Firmicutes, } \\
\text { Proteobacteria, Actinobacteria) }\end{array}$ & Sun et al., 2018 \\
\hline Fermented soy bean paste (doenjang) & $\begin{array}{l}\text { Tetragenococcus, Enterococcus, } \\
\text { Leuconostoc, Lactobacillus }\end{array}$ & Kim et al., 2016 \\
\hline
\end{tabular}

\section{Conclusion}

In the clinical field, microbial measurement is being accelerated and automated. However, in the food sector, rapid microbial evaluation technologies are not widespread. This is because the samples to be tested are not simple like water and blood. Foods contain many ingredients such as pigments, proteins, and lipids, which inhibit microbial measurement. Moreover, since the cost of the conventional medium-based method is low, introduction of a new method with high cost is often not preferred. Low cost, simple pre-treatment methods such as protein removal by isoelectric precipitation, and oil removal using surfactants has achieved rapid detection, identification and automation of microbial measurements in processed soy foods. For food companies, the ability to quickly judge the results of microbial tests means enhancing the microbial management system. Compared to the conventional culture method that relies heavily on human labor, automated methods enable each person to obtain similar results, aiding in the advancement of microbial test standardization. Consequently, food manufacturers can focus on making safer products. These findings are considered to contribute greatly in guaranteeing the delivery of safe and high-quality processed soy foods.

\section{Acknowledgments}

We would like thank to Editage (www.editage.com) for English language editing.

\section{References}

Ananchaipattana, C., Hosotani, Y., Kawasaki, S., Pongswat, S., Latiful, B. M., Isobe, S., \& Inatsu, Y. (2012). Bacterial contamination of soybean curd (tofu) sold in Thailand. Food Science and Technology Research, 18(4), 843-848. https://doi.org/10.3136/fstr.18.843

Angelakis, E., Million, M., Henry, M., \& Raoult, D. (2011). Rapid and accurate bacterial identification in probiotics and yoghurts by MALDI-TOF mass spectrometry. Journal of Food Science, 76(8), M568-M572. https://doi.org/10.1111/j.1750-3841.2011.02369.x

Arai, I., Sawayama, S., Nashimoto, K., Shimakita, T., \& Tashiro, Y. (2006). The evaluation of microbes enumeration in raw milk by fluorescent filter method. Milk Science, 55(1), 31-36.

Araki, E., Matsuzaki, T., Sekita, T., Saito, M., \& Matsuoka, H. (2010). Development of a density slicer for the simple collection of respective density layers after stepwise density gradient centrifugation. Biocontrol Science, 15(2), 39-43. https://doi.org/10.4265/bio.15.39

Barreiro, J. R., Braga, P. A.C., Ferreira, C. R., Kostrzewa, M., Maier, T., Wegemann. B., Böettcher, V., Eberlin, M. N., \& dos Santos, M. V. (2012). Nonculture-based identification of bacteria in milk by protein fingerprinting. Proteomics, 12(17), 2739-2745. https://doi.org/10.1002/pmic.201200053

Benoit, P. W., \& Donahue, D. W. (2003). Methods for rapid separation and concentration of bacteria in food that bypass time-consuming cultural enrichment. Journal of Food Protection, 66(10), 1935-1948.

https://doi.org/10.4315/0362-028X-66.10.1935 
Böhme, K., Fernández-No, I. C., Barros-Velázquez, J., Gallardo, J. M., Cañas, B., \& Calo-Mata, P. (2011). Rapid species identification of seafood spoilage and pathogenic Gram-positive bacteria by MALDI-TOF mass fingerprinting. Electrophoresis, 32(21), 2951-2965. https://doi.org/10.1002/elps.201100217

Boulos, L., Prevost, M., Barbeau, B., Coallier, J., \& Desjardins, R. (1999). LIVE/DEAD ${ }^{\circledR}$ BacLight ${ }^{\mathrm{TM}}$ : application of a new rapid staining method for direct enumeration of viable and total bacteria in drinking water. Journal of Microbiological Methods, 37(1), 77-86. https://doi.org/10.1016/S0167-7012(99)00048-2

Crowley, E. S., Bird, P. M., Torontali, M. K., Agin, J. R., Goins, D. G., \& Johnson, R. (2008). TEMPO® TVC for the enumeration of aerobic mesophilic flora in foods: Collaborative study. Journal of AOAC International, 92(1), 165-174. https://doi.org/10.1093/jaoac/92.1.165

Crowley, E., Bird, P. M., Torontali, M. K., Goetz, K., Agin, J. R., Goins, D. G., \& Johnson, R. (2010). TEMPO® EC for the enumeration of Escherichia coli in foods: collaborative study. Journal of AOAC International, 93(2), 576-586. https://doi.org/10.1093/jaoac/93.2.576

Ezeokoli, O. T., Adeleke, R. A., \& Bezuidenhout, C. C. (2018). Core bacterial community of soy-daddawa: insights from high-throughput DNA metabarcoding. LWT, 97, 61-66. https://doi.org/10.1016/j.lwt.2018.06.039

Diaper, J. P., Tither, K., \& Edwards, C. (1992). Rapid assessment of bacterial viability by flow cytometry. Applied Microbiology and Biotechnology, 38(2), 268-272. https://doi.org/10.1007/BF00174481

Fang, T. J., Chen, C. Y., \& Kuo, W. Y. (1999). Microbiological quality and incidence of Staphylococcus aureus and Bacillus cereus in vegetarian food products. Food Microbiology, 16(4), 385-391. https://doi.org/10.1006/fmic.1998.0256

Feldsine, P., Abeyta, C., \& Andrews, W. H. (2002). AOAC International methods committee guidelines for validation of qualitative and quantitative food microbiological official methods of analysis. Journal of AOAC International, 85(5), 1187-1200. https://doi.org/10.1093/jaoac/85.5.1187

Ferreira, L., Sánchez-Juanes, F., González-Ávila, M., Cembrero-Fuciños, D., Herrero-Hernández, A., González-Buitrago, J. M., \& Muñoz-Bellido, J. L. (2010). Direct identification of urinary tract pathogens from urine samples by matrix-assisted laser desorption ionization-time of flight mass spectrometry. Journal of Clinical Microbiology, 48(6), 2110-2115. https://doi.org/10.1128/JCM.02215-09

Freitas, R., Nero, L. A., \& Carvalho, A. F. (2009). Enumeration of mesophilic aerobes in milk: Evaluation of standard official protocols and Petrifilm aerobic count plates. Journal of Dairy Science, 92(7), 3069-3073. https://doi.org/10.3168/jds.2008-1705

Fukushima, H., Katsube, K., Hata, Y., Kishi, R., \& Fujiwara, S. (2007). Rapid separation and concentration of food-borne pathogens in food samples prior to quantification by viable-cell counting and real-time PCR. Applied and Environmental Microbiology, 73(1) 92-100. https://doi.org/10.1128/AEM.01772-06

Furukawa, Y., Katase, M., \& Tsumura, K. (2013). Evaluation of matrix-assisted laser desorption/ionization time-of-flight mass spectrometry for rapid identification of bacteria in processed soybean products. Journal of Food Research, 2(3), 104-109. https://doi.org/10.5539/jfr.v2n3p104

Gadkar, V. J., \& Filion, M. (2013). Quantitative real-time polymerase chain reaction for tracking microbial gene expression in complex environmental matrices. Current issues in Molecular Biology, 15(2), 45-58.

Gracias, K. S., \& McKillip, J. L. (2004). A review of conventional detection and enumeration methods for pathogenic bacteria in food. Canadian journal of microbiology, 50(11), 883-890. https://doi.org/10.1139/w04-080

Gu, J., Liu, T., Sadiq, F. A., Yang, H., Yuan, L., Zhang, G., \& He, G. (2018). Biogenic amines content and assessment of bacterial and fungal diversity in stinky tofu-A traditional fermented soy curd. LWT, 88, 26-34. https://doi.org/10.1016/j.lwt.2017.08.085

Han, B. Z., Beumer, R. R., Rombouts, F. M., \& Nout, M. R. (2001). Microbiological safety and quality of commercial sufu-a Chinese fermented soybean food. Food Control, 12(8), 541-547. https://doi.org/10.1016/S0956-7135(01)00064-0

Hettiarachchy, N. S., \& Kalapathy, U. (1997). Soybean protein products. In K. Liu (Ed.), Soybeans: Chemistry, Technology, and Utilization (pp. 379-411). New York: Chapman and Hall International Thomson Publishing. https://doi.org/10.1007/978-1-4615-1763-4_8

Hochel, I., Růžičková, H., Krásný, L., \& Demnerová, K. (2012). Occurrence of Cronobacter spp. in retail foods. 
Journal of Applied Microbiology, 112(6), 1257-1265. https://doi.org/10.1111/j.1365-2672.2012.05292.x

International Organization for Standardization. (2003). Microbiology of food and animal feeding stuffs. Horizontal method for the enumeration of microorganisms. Colony count technique at $30^{\circ} \mathrm{C}$. (ISO 4833:2003(en)). Retrieved from https://www.iso.org/obp/ui/\#iso:std:iso:4833:en

International Organization for Standardization. (2010). Preparation of test samples, initial suspension and decimal dilutions for microbiological examination. Specific rules for the preparation of milk and milk products (ISO 6887-5:2010). Retrieved from https://www.iso.org/standard/50306.html

Jagadeesan, B., Gerner-Smidt, P., Allard, M. W., Leuillet, S., Winkler, A., Xiao, Y., ... Grant, K. (2019). The use of next generation sequencing for improving food safety: Translation into practice. Food Microbiology, 79, 96-115. https://doi.org/10.1016/j.fm.2018.11.005

Jasson, V., Jacxsens, L., Luning, P., Rajkovic, A., \& Uyttendaele, M. (2010). Alternative microbial methods: An overview and selection criteria. Food Microbiology, 27(6), 710-730. https://doi.org/10.1016/j.fm.2010.04.008

Jepras, R. I., Carter, J., Pearson, S. C., Paul, F. E., \& Wilkinson, M. J. (1995). Development of a robust flow cytometric assay for determining numbers of viable bacteria. Applied and Environmental Microbiology, 61(7), 2696-2701. https://doi.org/10.1128/AEM.61.7.2696-2701.1995

Jung, J. Y., Lee, S. H., \& Jeon, C. O. (2014). Microbial community dynamics during fermentation of doenjang-meju, traditional Korean fermented soybean. International Journal of Food Microbiology, 185, 112-120. https://doi.org/10.1016/j.ijfoodmicro.2014.06.003

Katase, M., Tsuboi, S., \& Tsumura, K. (2013). Rapid enumeration of viable bacterial cells in processed soy products using an automated cell counting system. Food Control, 32(2), 501-504. https://doi.org/10.1016/j.foodcont.2013.01.015

Katase, M., \& Tsumura, K. (2011). Enumeration of micro-organisms in processed soy products with an automated most probable number method compared with standard plate method. Letters in Applied Microbiology, 53(5), 539-545. https://doi.org/10.1111/j.1472-765X.2011.03143.x

Katase, M., \& Tsumura, K. (2014). High-throughput identification of coliforms in processed soybean products using matrix-assisted laser desorption ionization time-of-flight mass spectrometry. Food Science and Technology Research, 20(5), 1093-1097. https://doi.org/10.3136/fstr.20.1093

Khan, M. M. T., Pyle, B. H., \& Camper, A. K. (2010). Specific and rapid enumeration of viable but nonculturable and viable-culturable gram-negative bacteria by using flow cytometry. Applied and Environmental Microbiology, 76(15), 5088-5096. https://doi.org/10.1128/AEM.02932-09

Kim, E., Cho, Y., Lee, Y., Han, S. K., Kim, C. G., Choo, D. W., Kim, Y. R., \& Kim, H. Y. (2017). A proteomic approach for rapid identification of Weissella species isolated from Korean fermented foods on MALDI-TOF MS supplemented with an in-house database. International Journal of Food Microbiology, 243, 9-15. https://doi.org/10.1016/j.ijfoodmicro.2016.11.027

Kim, T. W., Lee, J. H., Kim, S. E., Park, M. H., Chang, H. C., \& Kim, H. Y. (2009). Analysis of microbial communities in doenjang, a Korean fermented soybean paste, using nested PCR-denaturing gradient gel electrophoresis. International Journal of Food Microbiology, 131(2-3), 265-271. https://doi.org/10.1016/j.ijfoodmicro.2009.03.001

Kim, Y. S., Kim, M. C., Kwon, S. W., Kim, S. J., Park, I. C., Ka, J. O., \& Weon, H. Y., (2011). Analyses of bacterial communities in meju, a Korean traditional fermented soybean bricks, by cultivation-based and pyrosequencing methods. The Journal of Microbiology, 49(3), 340-348. https://doi.org/10.1007/s12275-011-0302-3

Kim, M. J., Kwak, H. S., Jung, H. Y., \& Kim, S. S. (2016). Microbial communities related to sensory attributes in Korean fermented soy bean paste (doenjang). Food Research International, 89, 724-732. https://doi.org/10.1016/j.foodres.2016.09.032

Kobayashi, A., Okuyama, S., Kenmotsu, K., Yamagata, H., Uchida, K., Fukumura, K., \& Nakagawa, H. (2008). Study of enumeration of microorganisms in food samples with automated enumeration system, TEMPO. Japanese Journal of Food Microbiology, 25, 120-126. https://doi.org/10.5803/jsfm.25.120

Kuda, T., Izawa ,Y., Yoshida, S., Koyanagi, T., Takahashi, H., \& Kimura, B. (2014). Rapid identification of Tetragenococcus halophilus and Tetragenococcus muriaticus, important species in the production of salted 
and fermented foods, by matrix-assisted laser desorption ionization-time of flight mass spectrometry (MALDI-TOF MS). Food Control, 35(1), 419-425. https://doi.org/10.1016/j.foodcont.2013.07.039

Kunicka, A. (2007). TEMPO system in microbiological analysis of spices and food additives. Polish Journal of Food and Nutrition Sciences, 57(3A), 67-69. https://doi.org/10.1016/j.jbiotec.2007.07.119

Lahtinen, S. J., Gueimonde, M., Ouwehand, A. C., Reinikainen, J. P., \& Salminen, S. J. (2006). Comparison of four methods to enumerate probiotic bifidobacteria in a fermented food product. Food Microbiology, 23(6), 571-577. https://doi.org/10.1016/j.fm.2005.09.001

Lay Jr, J. O. (2001). MALDI-TOF mass spectrometry of bacteria. Mass spectrometry reviews, 20(4), 172-194. https://doi.org/10.1002/mas.10003

Lee, M. H., Li, F. Z., Lee, J., Kang, J., Lim, S. I., \& Nam, Y. D. (2017). Next-generation sequencing analyses of bacterial community structures in soybean pastes produced in Northeast China. Journal of Food Science, 82(4), 960-968. https://doi.org/10.1111/1750-3841.13665

Masakiyo, Y., Yoshida, A., Takahashi, Y., Shintani, Y., Awano, S., Ansai, T., Sawayama, S., Shimakita, T., \& Takehara, T. (2010). Rapid LED-based fluorescence microscopy distinguishes between live and dead bacteria in oral clinical samples. Biomedical Research, 31(1), 21-26. https://doi.org/10.2220/biomedres.31.21

Mazzeo, M. F., Sorrentino, A., Gaita, M., Cacace, G., Stasio, M. D., Facchiano, A., Comi, G., Malorni, A., \& Siciliano, R. A. (2006). Matrix-assisted laser desorption ionization-time of flight mass spectrometry for the discrimination of food-borne microorganisms. Applied and Environmental Microbiology, 72(2), 1180-1189. https://doi.org/10.1128/AEM.72.2.1180-1189.2006

Miyanaga, K., Takano, S., Morono, Y., Hori, K., Unno, H., \& Tanji, Y. (2007). Optimization of distinction between viable and dead cells by fluorescent staining method and its application to bacterial consortia. Biochemical Engineering Journal, 37(1), 56-61. https://doi.org/10.1016/j.bej.2007.03.007

Nam, Y. D., Yi, S. H., \& Lim, S. I. (2012). Bacterial diversity of cheonggukjang, a traditional Korean fermented food, analyzed by barcoded pyrosequencing. Food Control, 28(1), 135-142. https://doi.org/10.1016/j.foodcont.2012.04.028

Nishimura, M., Shimakita, T., Kamiya, E., Tashiro, Y., \& Kogure, K. (2006). Use of an automatic cell-counting system with LED illumination for enumeration of marine bacteria. Fisheries Science, 72(4), 723-727. https://doi.org/10.1111/j.1444-2906.2006.01210.x

Nishimura, M., Shimakita, T., Matsuzaki, T., Tashiro, Y., \& Kogure, K. (2008). Automatic counting of FISH-labeled microbes by an LED illuminated detecting apparatus. Fisheries Science, 74(2), 405-410. https://doi.org/10.1111/j.1444-2906.2008.01537.x

Ootsubo, M., Shimizu, T., Tanaka, R., Sawabe, T., Tajima, K., \& Ezura, Y. (2003). Seven-hour fluorescence in situ hybridization technique for enumeration of Enterobacteriaceae in food and environmental water sample. Journal of Applied Microbiology, 95(6), 1182-1190. https://doi.org/10.1046/j.1365-2672.2003.02051.x

Official Methods of Analysis Online. (2005). Standard Pour Plate Method (AOAC Official Method 966.23). Retrieved from http://www.eoma.aoac.org/methods/info.asp?ID=46660

Owen, M., Willis, C., \& Lamph, D. (2010). Evaluation of the TEMPO® most probable number technique for the enumeration of Enterobacteriaceae in food and dairy products. Journal of Applied Microbiology, 109(5), 1810-1816. https://doi.org/10.1111/j.1365-2672.2010.04810.x

Pascall, M. A., Ravishankar, S., Ghiron, K., Lee, B. T., \& Johannessen, J. N. (2006). Evaluation of magnetic resonance for detection of bacterial contamination in low-acid, shelf-stable packaged soymilk. Journal of Food Protection, 69(7), 1668-1674. https://doi.org/10.4315/0362-028X-69.7.1668

Patro, J. N., Ramachandran, P., Barnaba, T., Mammel, M. K., Lewis, J. L., \& Elkins, C. A. (2016). Culture-independent metagenomic surveillance of commercially available probiotics with high-throughput next-generation sequencing. MSphere, 1(2), e00057-16. https://doi.org/10.1128/mSphere.00057-16

Paulsen, P., Schopf, E., \& Smulders, F. J. M. (2006). Enumeration of total aerobic bacteria and Escherichia coli in minced meat and on carcass surface samples with an automated most-probable-number method compared with colony count protocols. Journal of Food Protection, 69(10), 2500-2503. https://doi.org/10.4315/0362-028X-69.10.2500

Paulsen, P., Borgetti, C., Schopf, E., \& Smulders, F. J. M. (2008). Enumeration of Enterobacteriaceae in various 
foods with a new automated most-probable-number method compared with Petrifilm and International Organization for Standardization procedures. Journal of Food Protection, 71(2), 376-379. https://doi.org/10.4315/0362-028X-71.2.376

Petenate, A. M., \& Glatz, C. E. (1983). Isoelectric precipitation of soy protein: I. Factors affecting particle size distribution. Biotechnology and Bioengineering, 25(12), 3049-3058. https://doi.org/10.1002/bit.260251219

Pettipher, G. L., \& Rodrigues, U. M. (1982). Rapid enumeration of microorganisms in foods by the direct epifluorescent filter technique. Applied and Environmental Microbiology, 44(4), 809-813. https://doi.org/10.1128/AEM.44.4.809-813.1982

Préstamo, G., Lesmes, M., Otero, L., \& Arroyo, G. (2000). Soybean vegetable protein (tofu) preserved with high pressure. Journal of Agricultural and Food Chemistry, 48(7), 2943-2947. https://doi.org/10.1021/jf991251y

Rantsiou, K., Kathariou, S., Winkler, A., Skandamis, P., Saint-Cyr, M. J., Rouzeau-Szynalski, K., \& Amézquita, A. (2018). Next generation microbiological risk assessment: opportunities of whole genome sequencing (WGS) for foodborne pathogen surveillance, source tracking and risk assessment. International Journal of Food Microbiology, 287, 3-9. https://doi.org/10.1016/j.ijfoodmicro.2017.11.007

Samson, R. A., Van Kooij, J. A., \& De Boer, E. (1987). Microbiological quality of commercial tempeh in the Netherlands. Journal of Food Protection, 50(2), 92-94. https://doi.org/10.4315/0362-028X-50.2.92

Sarkar, P. K., Tamang, J. P., Cook, P. E., \& Owens, J. D. (1994). Kinema-a traditional soybean fermented food: proximate composition and microflora. Food Microbiology, 11(1), 47-55. https://doi.org/10.1006/fmic.1994.1007

Schrader, C., Schielke, A., Ellerbroek, L., \& Johne, R. (2012). PCR inhibitors-occurrence, properties and removal. Journal of Applied Microbiology, 113(5), 1014-1026. https://doi.org/10.1111/j.1365-2672.2012.05384.x

Shimakita, T., Tashiro, Y., Katsuya, A., Saito, M., \& Matsuoka, H. (2006). Rapid separation and counting of viable microbial cells in food by nonculture method with bioplorer, a focusing-free microscopic apparatus with a novel cell separation unit. Journal of Food Protection, 69(1), 170-176. https://doi.org/10.4315/0362-028X-69.1.170

Shimakita, T., Yamamoto, H., Nakamura, T., Fujimori, A., Ide, T., Tashiro, Y., Saito, M., \& Matsuoka, H. (2007). Rapid count of microbial cells in dialysate. Therapeutic Apheresis and Dialysis, 11(5), 363-369. https://doi.org/10.1111/j.1744-9987.2007.00500.x

Silva, B. O., Caraviello, D. Z., Rodrigues, A. C., \& Ruegg, P. L. (2005). Evaluation of Petrifilm for the isolation of Staphylococcus aureus from milk samples. Journal of Dairy Science, 88(8), 3000-3008. https://doi.org/10.3168/jds.S0022-0302(05)72980-5

de Sousa, G. B., Tamagnini, L. M., González, R. D., \& Budde, C. E. (2005). Evaluation of Petrifilm TM method for enumerating aerobic bacteria in Crottin goat's cheese. Revista Argentina de microbiologia, 37(4), 214-216.

Stevens, K. A., \& Jaykus, L. A. (2004). Bacterial separation and concentration from complex sample matrices: a review. Critical Reviews in Microbiology, 30(1), 7-24. https://doi.org/10.1080/10408410490266410

Sun, X., Lyu, G., Luan, Y., Zhao, Z., Yang, H., \& Su, D. (2018). Analyses of microbial community of naturally homemade soybean pastes in Liaoning Province of China by Illumina Miseq sequencing. Food Research International, 111, 50-57. https://doi.org/10.1016/j.foodres.2018.05.006

Thrane, M., Paulsen, P. V., Orcutt, M. W., \& Krieger, T. M. (2017). Soy protein: Impacts, production, and applications. In Nadathur, S. R., Wanasundara, J. P. D. and Scanlin, L. (Eds.), Sustainable protein sources (pp. 23-45). Cambridge: Academic Press. https://doi.org/10.1016/B978-0-12-802778-3.00002-0

Torlak, E., Akan, I. M., \& Gökmen, M. (2008). Comparison of TEMPO® EC and TBX medium for the enumeration of Escherichia coli in cheese. Letters in Applied Microbiology, 47(6), 566-570. https://doi.org/10.1111/j.1472-765X.2008.02467.x

Tsumura, K., Saito, T., Kugimiya, W., \& Inouye, K. (2004). Selective proteolysis of the glycinin and $\beta$-conglycinin fractions in a soy protein isolate by pepsin and papain with controlled $\mathrm{pH}$ and temperature. Journal of Food Science, 69(5), C363-C367. https://doi.org/10.1111/j.1365-2621.2004.tb10698.x

Tsumura, K. (2009). Improvement of the physicochemical properties of soybean proteins by enzymatic hydrolysis. Food Science and Technology Research, 15(4), 381-388. https://doi.org/10.3136/fstr.15.381 
Tsumura, K., \& Tsuboi, S. (2012). Rapid enumeration of microbial cells in solubilized soymilk by an automatic cell counting system with LED illumination. Food Science and Technology Research, 18(2), 183-186. https://doi.org/10.3136/fstr.18.183

Tuitemwong, K., \& Fung, D. Y. (1991). Microbiological study of tofu. Journal of Food Protection, 54(3), 212-216. https://doi.org/10.4315/0362-028X-54.3.212

UNESCO. (2013). Washoku, traditional dietary cultures of the Japanese, notably for the celebration of New Year. https://ich.unesco.org/en/decisions/8.COM/8.17. Accessed 15 June 2020.

Vasavada, P. C., \& White, C. H. (1993). Developing methodology for microbiological evaluation of milk and dairy products-an introduction. Journal of Dairy Science, 76(10), 3099-3100. https://doi.org/10.3168/jds.S0022-0302(93)77648-1

Woo, S. G., Lee, S. Y., Choi, G. W., Hong, Y. J., Lee, S. M., Park, K. G., \& Eom, Y. B. (2015). Bacterial identification and detection of equol in Korean soybean paste. Korean Journal of Clinical Laboratory Science, 47(4), 286-291. https://doi.org/10.15324/kjcls.2015.47.4.286

Wu, J., Tian, T., Liu, Y., Shi, Y., Tao, D., Wu, R., \& Yue, X. (2018). The dynamic changes of chemical components and microbiota during the natural fermentation process in Da-Jiang, a Chinese popular traditional fermented condiment. Food Research International, 112, 457-467. https://doi.org/10.1016/j.foodres.2018.06.021

Xie, M., An, F., Wu, J., Liu, Y., Shi, H., \& Wu, R. (2019). Meta-omics reveal microbial assortments and key enzymes in bean sauce mash, a traditional fermented soybean product. Journal of the Science of Food and Agriculture, 99(14), 6522-6534. https://doi.org/10.1002/jsfa.9932

Yamaguchi, N., Baba, T., Nakagawa, S., Saito, A., \& Nasu, M. (2007). Rapid monitoring of bacteria in dialysis fluids by fluorescent vital staining and microcolony methods. Nephrology Dialysis Transplantation, 22(2), 612-616. https://doi.org/10.1093/ndt/gfl675

Yamaguchi, N., Sasada, M., \& Nasu, M. (2009). Rapid detection of starved Escherichia coli with respiratory activity in potable water by signal-amplified in situ hybridization following formazan reduction. Microbes and Environments, 24(4), 286-290. https://doi.org/10.1264/jsme2.ME09144

Yamaguchi, N., Sasada, M., Yamanaka, M., \& Nasu, M. (2003). Rapid detection of respiring Escherichia coli O157: H7 in apple juice, milk, and ground beef by flow cytometry. Cytometry Part A: the journal of the International Society for Analytical Cytology, 54(1), 27-35. https://doi.org/10.1002/cyto.a.10045

Zhou, H., Tian, Y., \& Wang, R. (2017). Spoilage Microorganisms in Bean Products. In Y. Wang, W. Zhang \& L. Fu, (Eds.), Food Spoilage Microorganisms: Ecology and Control (pp. 23-35). Boca Raton: CRC Press.

\section{Copyrights}

Copyright for this article is retained by the author(s), with first publication rights granted to the journal.

This is an open-access article distributed under the terms and conditions of the Creative Commons Attribution license (http://creativecommons.org/licenses/by/4.0/). 